\title{
RICHARD GORDON VIVIAN, 1908-1966
}

\section{Roland Richert}

THE CLOSELY allied fields of Southwestsuffered a severe loss in the untimely death of Gordon Vivian on April 29, 1966, of leukemia, at Globe, Arizona. During the $261 / 2$ years that Gordon was employed by the federal government, he contributed more to our knowledge of preserving prehistoric sites than anyone before him. Besides ruins stabilization projects, important archaeological investigations in Chaco Canyon National Monument were in progress when death overtook him.

It has been my rare privilege to be closely associated with Gordon for 15 years as his assistant. Since there is no one who will ever quite replace him, our best course is to carry out the specialized work for which he so ingeniously established the guidelines.

Richard Gordon Vivian was born in Laurium, Michigan, in the heart of the Lake Superior copper district, on August 27, 1908, and he lived there until he was 10 years old, except for one year, 1913, when he was in Globe, Arizona, with his mother and grandfather. The grandfather was employed that year in the Old Dominion Mine while his father, Mr. Stanley Vivian, was a pattern maker in the northern Michigan mines and also did foundry work. Both men were skilled carpenters and cabinetmakers, a fact which considerably influenced Gordon.

The story goes that his father built a rather unique wood tool box. Gordon coveted this item very much but was informed by his elders that he could not come into possession of it until and unless he approximated the craftsmanship of his progenitors. With this goal firmly in mind, he not only learned as much as possible about carpenter tools and their use, but he proceeded to construct a precise-scale model of the original box, thus proving beyond all doubt his claim to an heirloom. This incident set the tone of his life. (I am indebted to Mrs. Vivian for this version of a family legend and for other factual material herein.)

Of Cornish-English descent, Gordon had a quiet reserve and firm determination about him which characterized his every action. Nevertheless, his humor was profound, and, if properly approached, he was a wonderful story- teller. His fund of anecdotes about the Navajo and incidents at Chaco Canyon was limitless, and, as often as not, he was the butt of the jokes. Being an outdoor man he enjoyed big game hunting and became a marvelous cook - a skill which was virtually thrust upon him during a 21-year tour of isolated field duty at Chaco Canyon when Mrs. Vivian established a second home in Albuquerque during the winters so that the children could obtain a formal education.

In 1918 the family moved from Michigan to Albuquerque where his father established a dairy business. Gordon's early interest in local archaeology developed while he was a high school student in Albuquerque. He visited numerous sites in the Rio Grande and Rio Puerco drainages, mostly on bicycle. He also covered much of New Mexico on two wheels. At this time he became particularly interested in the historic contact sites which eventually led to his master's thesis on Bandelier's Puaray.

In 1927 he entered the University of New Mexico, where 4 years later he received a B.A. degree with a major in archaeology and a minor in geology. The venerable Dr. E. L. Hewett was head of the Department of Anthropology at that time besides having a hand in numerous extracurricular activities. In 1929 Gordon was a student of the first field school of the University of New Mexico in Chaco Canyon, where work was begun on the site of Chettro Kettle.

During the 7-year period, 1929-35, he served as truck driver and field assistant for Dr. Hewett, excavating and partly restoring the great kiva of Casa Rinconada in 1931-33, was on the staff of the field school at Jemez in 1934, and excavated at Puaray and Kuaua in 1935, skillfully jacketing and removing murals at the latter site. The year 1931 was a definite turning point in his career. He requested that Hewett recommend him for the late Dr. Frank $\mathrm{H}$. $\mathrm{H}$. Roberts' dig at Whitewater. Hewett dissuaded him on the grounds that sites in Chaco were much more impressive and important and that Gordon would simply be wasting his time digging unspectacular pit houses. Meanwhile, he earned a master's degree at the University of New Mexico in 1932. 


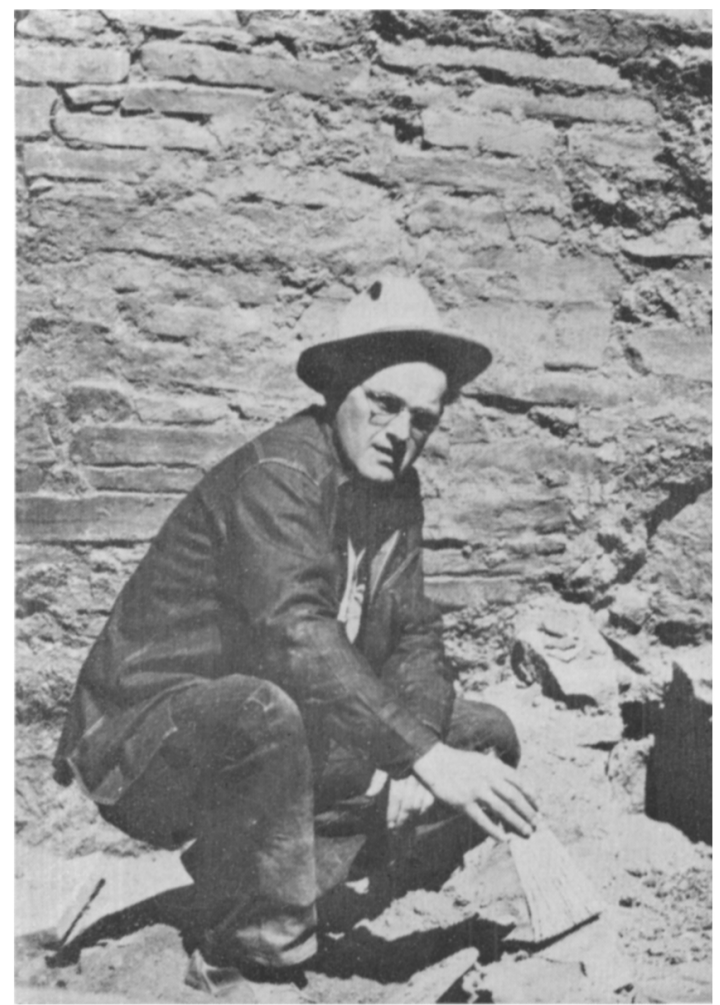

Richard GoRdon Vivian

During this period, the late Dr. Paul Reiter was also one of Dr. Hewett's assistants. A close friendship and professional alliance developed between Gordon and Paul, a heady combination which sometimes erupted harmlessly in clashes with authority and inventive college pranks.

Following a university education, and with considerable field experience under his belt, Gordon had some aspirations to become a teacher, but one year of this experience in 1935-36 at Hockaday College, then an exclusive girls' school in Dallas, Texas, cured him more or less permanently of the idea, although he would have undoubtedly been an excellent professor of Southwestern archaeology at the university level.

Gordon was married to Myrtle Perce, the daughter of Mr. and Mrs. George Perce, in Santa Fe on November 19, 1934. Mr. Perce was an employee of the Indian Service. Myrtle had to become a real trouper and camper to keep up with Gordon. An expert photographer and a student of anthropology in her own right, as well as being a highly competent public school teacher, Myrtle often vied with her husband as to who could take the best pictures, and the two frequently debated the various phases of his work as a government employee. Theirs was obviously an overall harmonious and influential home life despite government orders, red tape, and sometimes disruptive reorganizations, because it is significant that their son, Gwinn, is following in his father's footsteps.

Fortunately for the National Park Service, Gordon was back in Chaco Canyon in 1936-37, constructing the permanent field headquarters for the University of New Mexico and the School of American Research. He built a hogan in 1936 as the first home in Chaco Canyon. On July 7, 1937, Mr. Robert Harris, Engineer Foreman, was appointed by the National Park Service to establish an Indian CCC Mobile Unit with the objective of performing ruins stabilization on the sites in Chaco Canyon. Pueblo Bonito, covering some three acres and the largest surface ruin of its type in the United States, was in bad shape. Mr. Harris resigned to attend school three months later, and Gordon was placed in charge. This avowed experiment of stabilizing ruins by a Service-sponsored crew proved so successful under his guidance and leadership, that the Unit was placed on a permanent basis with regularly appropriated congressional funds. The crew concentrated on Pueblo Bonito from 1937-41, bringing it up to maintenance status. In 1941 Gordon stabilized the large West Ruin at Aztec.

When severe wartime restrictions forced the closure of Mobile Unit activities from 1942-46, Gordon obtained a position with the Army Engineer Corps stationed at Pecos, Texas. This experience proved valuable later at Chaco Canyon in testing materials most suited to ruins repair and stabilization.

He re-entered the National Park Service in 1946, serving briefly as a ranger at Casa Grande Ruins National Monument, pending re-establishment of the Mobile Unit on a peacetime footing. From 1947 to 1958 the Unit, under his direction and using Chaco as a field base, traveled widely throughout the Southwest to bring some 80 individual sites in 16 areas up to maintenance status. By this time Gordon had amassed considerable specialized data on methods, materials, and techniques and had systematically recorded and evaluated those items which proved most effective and durable. By drawing upon this experience and coming 
to grips with the problem of stabilizing and maintaining prehistoric sites, which has as many ramifications as there are individual structures, Gordon originated the Prehistoric Ruins Stabilization Handbook. Adapted for field use, this handy guidebook outlines the problem and standardizes the methods, materials, techniques, and means of recordation. Moreover, he successfully resolved the two conflicting objectives which must be satisfied in stabilizing any prehistoric structure - authentic appearance and permanence, the requirements of sound building practice. This book has been widely sought and acclaimed both within and without the government.

He participated in the increasingly important field of state and agency cooperation in the preservation and presentation of historic and prehistoric sites by providing necessary cost estimates and recommended procedures based on inspections of the sites, assessment of job requirements, and submittal of special reports. $\mathrm{He}$ also trained employees in the Ruins Stabilization Unit to perform these functions in addition to their regular duties. Because of his technical knowledge and experience, he was called upon to solve special problems concerning excavation and stabilization-preservation in distant areas: Russell Cave, Alabama; City of Refuge, Hawaii; Fort Randall, South Dakota; and Harpers Ferry, Virginia. His official correspondence throughout the years contains requests for consultive advice from foreign countries such as Jordan and Peru.

Gordon derived considerable archaeological knowledge of Chaco Canyon and the San Juan area through serendipity and chance, abetted by his sharp powers of observation and an analytical mind. Besides repairing and weatherproofing individual ruinous walls, stabilization involves a variety of related operations: minor excavations to determine soundness of wall foundations; grading for site drainage; installing dry barrels for interior room drainage; removal of fill behind walls to relieve pressure. In many instances, these were activities which he performed in sites that had been excavated and reported on by others. These tasks he viewed as challenging opportunities for turning up many unsuspected features, as witness his findings in the so-called $\mathrm{Bc}$ sites, Chettro Kettle, Pueblo Bonito, Pueblo del Arroyo, and many others. The combined excavation-stabilization of a practically virgin site, Kin Kletso, was his assignment in 1951, and he made the most of it, as his report testifies. It is my opinion that this publication, to say nothing of the exemplary stabilization and corresponding architectural records compiled for the site, offers the most perceptive synthesis of Chaco to date and, along with other major publications, ranks Gordon in ability with outstanding men like Kidder and Morris, both of whom he admired greatly.

His long residence in Chaco, much of it concurrent with excavations conducted by the University of New Mexico and the School of American Research, enabled Gordon to be an eyewitness to many important findings, thus leaving him among the last few persons - if not the last - with a comprehensive knowledge of Chaco Canyon.

In 1958 he was named Supervisory Archaeologist to head up the Southwest Archaeological Center at Globe, a field branch of the Washington Office. Relieved to a considerable extent of field duties, the next 8 years were the most fruitful and productive of his career. He grew tremendously in stature, handling both administrative duties and writing up his researches. Besides pulling together Chaco archaeology, he found time not only to do some additional field work at Una Vida Ruin, Chaco, and Gila Cliff Dwellings, but also to conduct experiments in stabilizing soil structures by electro-chemical methods. It is tragic that his career was cut short at the height of productivity because he had just discovered an amazing complex of water conservation and distribution systems in Chaco Canyon. Reports covering these irrigation systems and the unique collection of painted wood material from Chettro Kettle, found in 1947 incidental to stabilization, will be completed by others.

To his workmen, the Navajos, he was respectfully known as Nataani Nez, the Big Boss. Under his direction many of them became skilled masons in ruins repair and expert diggers. His association with the Chaco Navajo made him a legendary figure, but it was not without incident. Once during a discussion period following a safety lecture - all of which had to be laboriously translated through an interpreter - one old Indian, evidently thinking of his stomach, got up and made a speech which, boiled down in translation, was: "When do we get paid?" On another occasion during the height of the ceremonial season and when 
absenteeism was above normal, Gordon fell from a ladder and dangled by one leg. Word spread quickly and attendance improved.

He was also a practical man. The day Threatening Rock fell, on January 22, 1941, Gordon was on the south side of the Canyon, soon lamenting the fact that his superannuated cement mixer was still standing upright and unscathed amid some 40,000 tons of debris, and he was thus deprived, even by an Act of God, of obtaining a badly-needed replacement.

About 4 years ago it was discovered that Gordon had leukemia. Despite the knowledge that his disease was terminal, he retained a remarkable vitality and a clear mind. Bravely and uncomplainingly fighting against time, his was truly a heroic accomplishment in seeing through to publication three of his most important monographs during serious illness. He remained active on the job every possible minute up until the final 6 weeks of hospitalization.

In the words of Mr. Dan Beard, Regional Director of the National Park Service, "Gordon's death is a real loss to the Service not only because of the tremendous contributions he has made over the years but also because he was such an outstanding representative of the National Park Service and a fine friend to all who knew him."

He is survived by his wife, Myrtle, of Globe; two daughters, Mrs. Ruth Gebman and Mrs. Anne Lovato, of Albuquerque; one son, $\mathrm{Mr}$. Gwinn Vivian, of Tucson; his mother, Mrs. Millie Vivian, of Albuquerque; one sister; and two grandchildren.

On March 7, 1953, the National Park Service honored Gordon by presenting him the Meritorious Service Award in recognition of his outstanding contribution to ruins stabilization and the related field of archaeology.

The following list of published works does not do justice to the volume of Gordon's writings. Not enumerated here for lack of space are some 40-50 Ruins Stabilization Reports in bound, manuscript form which are in themselves accurate and detailed architectural histories of as many sites.

\section{BIBLIOGRAPHY 1934}

The Excavation of Bandelier's Puaray. El Palacio, Vol. 37, Nos. 19-20, pp. 153-61. Santa Fe.

\section{5}

Frescoes Uncovered at Kuaua. El Palacio, Vol. 38, Nos. $9-11$, p. 61. Santa Fe.
The Murals at Kuaua. El Palacio, Vol. 38, Nos. 21-23, pp. 113-19. Santa Fe.

\section{0}

New Rooms and Kiva Found in Pueblo Bonito. Southwestern Monuments, February, pp. 127-30. Coolidge.

1948

The "General" Carved His Name. New Mexico Magazine, Vol. 26, No. 4, p. 16. Santa Fe.

\section{9}

Pre-historic Handy Man. New Mexico Magazine, Vol. 27, No. 6, p. 15. Santa Fe.

\section{4}

Review: "Kiva Mural Decorations at Awatovi and Kawaika-a with a Survey of Other Wall Paintings in the Pueblo Southwest," by Watson Smith. American Journal of Archaeology, Vol 58, No. 1, pp. 180-2. Brattleboro, Vermont.

\section{6}

Alcove House at NA 5700. Plateau, Vol. 29, No. 1, pp. 6-11. Flagstaff.

Review: "The Material Culture of Pueblo Bonito," by Neil M. Judd. American Antiquity, Vol. 21, No. 3, pp. 322-4. Salt Lake City.

\section{7}

Two Navaho Baskets. El Palacio, Vol. 64, Nos. 5-6, pp. 145-55. Santa Fe.

\section{9}

The Hubbard Site and Other Tri-Wall Structures in New Mexico and Colorado. National Park Service Archeological Research Series No. 5. Government Printing Office, Washington.

\section{0}

(with Paul Reiter) The Great Kivas of Chaco Canyon and Their Relationships. School of American Research Monograph No. 22. Santa Fe.

\section{2}

Prehistoric Ruins Stabilization Handbook (Revised from 1949 edition). Department of Interior, Duplicating Section, Washington.

\section{4}

Gran Quivira: Excavations in a 17th Century Jumano Pueblo. National Park Service Archeological Research Series No. 8. Government Printing Office, Washington.

\section{5}

The Three-C Site, An Early Pueblo II Ruin in Chaco Canyon, New Mexico. University of New Mexico Publications in Anthropology No. 13. University of New Mexico Press, Albuquerque.

(with Tom W. Mathews) Kin Kletso, A Pueblo III Community in Chaco Canyon, New Mexico. Southwestern Monuments Association Technical Series No. 6. Globe.

National Park Service

Globe, Arizona

August, 1966 